Research Article

\title{
Floristic and Phytoclimatic Study of a Sacred Grove Vegetation of West Midnapore District, West Bengal, India
}

\author{
Uday Kumar Sen *, Ram Kumar Bhakat \\ Department of Botany and Forestry, Vidyasagar University, Midnapore 721102, India
}

Article history:

Submission November 2018

Revised December 2018

Accepted January 2019

*Corresponding author:

E-mail: uudaysen@gmail.com

\begin{abstract}
Traditional cultural and religious beliefs and practices play a crucial role in the conservation of the environment and biodiversity in the form of the sacred groves. The present study was carried out to explore the plant resources, their biological spectrum, leaf size spectra, the conservation status of a sacred grove, locally known as Narampur Barapir Astana (NBA) in West Midnapore district of West Bengal in India. Floristic list of the study revealed that the vegetation of NBA was diverse and composed of 277 species belonging to 238 genera distributed over 77 families under 36 orders according to APG IV classification. The dominant order and family in terms of species richness were Lamiales 27 (9.75\%) and Fabaceae $32(11.55 \%)$ respectively. The biological spectrum shows the study area was classified as "thero-chamae-cryptophytic" type of phytoclimate. As regards the leaf size spectra, mesophyll 56 (20.22\%) was found to be high. The study area being a sacred grove is fairly undisturbed. For the long-term conservation of germplasm of the grove some recommendations are suggested.
\end{abstract}

Keywords: APG IV, biodiversity conservation, biological spectrum, phytoclimate, sacred grove

\section{Introduction}

Since the ancient days setting aside pockets of landscape or forest land has been the practice in India, as elsewhere in many parts of the world. Protecting these biological resources more specifically, a religious tag was annexed which accommodated over the years as a key factor in conservation through the mechanism of sacred groves [1]. It thus represents a tradition of conservation by the people much prior to the modern concepts of "Biosphere reserves" [2].

Sacred groves are surviving patches of pristine tropical forests, infrequently degraded by the human activities, but were protected, modeled by the local people and act as a historical marker, ecological and archaeological indicators. There was a general conception among the ancient people that the godly element was actively at work in places of natural sacred sites. Hence the vegetation was sacred to the adjacent people. Such sites persist to the present day and has a significant role at various ecological levels [3 - 7].

Plant's adaptation determines a life form to certain ecological conditions; thus, it is an essential physiognomic characteristic that has been widely used in vegetation analysis. It indicates macro and microclimate as well as human disturbances of a specific area [8]. Raunkiaer [9] proposed the term "Biological Spectrum" to express both the life-form distribution in flora and the phytoclimate under which the prevailing life-forms evolved. Under this system, plant species may be grouped into five main classes, i.e., phanerophytes, chamaephytes, hemicryptophytes, cryptophytes, and therophytes. The percentage of various life form classes put together is called as the biological spectrum. Raunkiaer [9] constructed a normal spectrum, which may act as a model, against which various life form spectra may be compared. Raunkiaer's normal spectrum indicates a phanerophytic community and the deviation (from it) determines the phytoclimate of a habitat. 


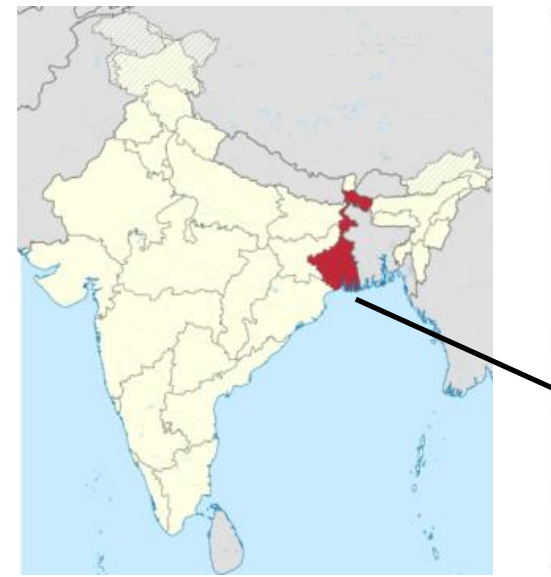

(a)

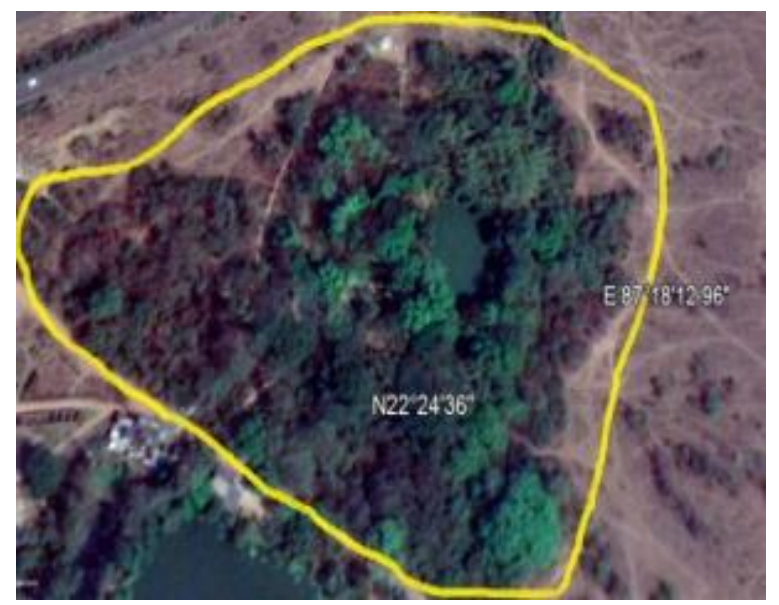

(d)

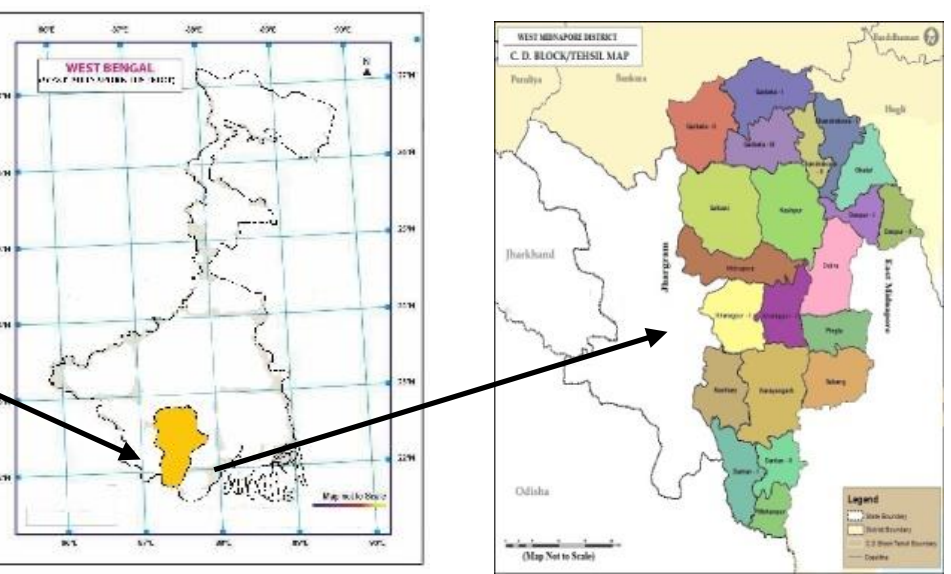

(b) (c)

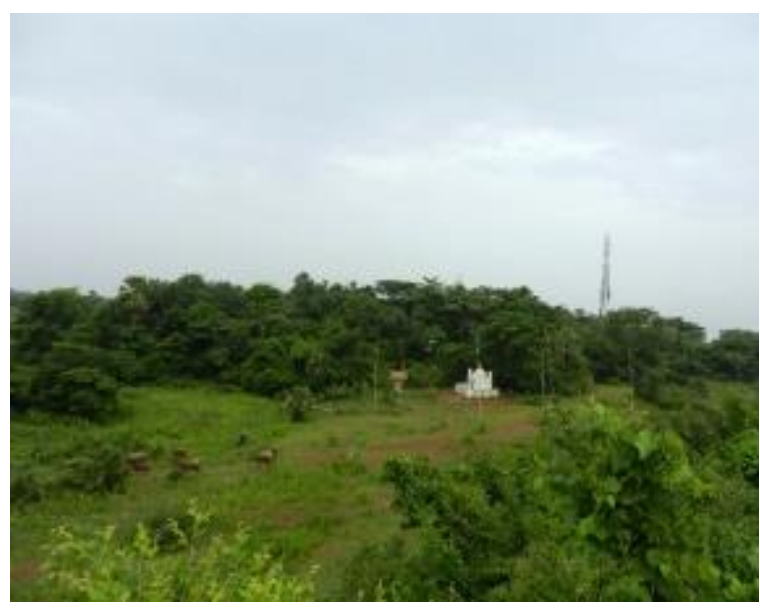

(e)

Figure 1. Location of the study area (India (a), West Bengal with West Midnapore district (b), West Midnapore district with Midnapore Sadar block (c), Google Earth image showing NBA sacred grove (d), and NBA sacred grove(e))

The occurrence of similar biological spectra in different regions indicates similar climatic conditions. So, the differences between normal spectrum and biological spectrum life forms may point out which life form characterizes the phytoclimate or vegetation.

Climatic types may be characterized by the prevailing plant life forms in the plant communities under a specific climatic regime [9-12]. The biological spectra of the Indian region are related to specific edaphic, altitudinal and climatic factors [13-17]. A life-form study is thus an important tool in vegetation description, ranking next to floristic composition. The biological spectrum is thus useful as an index of the health status of the forested landscape. When worked out at periodic intervals, the biological spectrum may set the guidelines for optimization and eco-restoration of a community.
Life form may also be categorized using leaf size i.e., leptophylls, nanophyll, microphyll, notophyll, mesophyll, macrophyll, and megaphyll. It has some justification for using a leaf size, based on percentages of the different leaf sizes present, to characterize different vegetation types. However, light intensity and soil conditions, mainly available nitrogen and phosphorus; have also a significant influence on leaf size even within the same genotype [18]. The present study of a sacred grove, thus, could be used as an example in India for other sacred groves in general and phytoclimatic study in particular.

\section{Material and Methods Study site}

The present sacred grove (latitude $22^{\circ} 24^{\prime} 36.23^{\prime \prime}-22^{\circ} 24^{\prime} 40.32^{\prime \prime} \mathrm{N}$ and longitude $87^{\circ}$ 
$18^{\prime} 09.75^{\prime \prime}-87^{\circ} 18^{\prime} 09.82^{\prime \prime}$ E, elevation 32 - 37 m asl), popularly known as NBA (Narampur Barapirer Astana) [named after Syed Shah Murshed Ali Al Kadri, who was popularly known as Pir (saint) and Astana means his meditation place], is situated at the northern bank of the Kansabati river under Midnapore Sadar block of West Midnapore district in West Bengal (Figure 1).

\section{The Scared grove}

The grove is located at the southwestern outskirts of Midnapore town in Streeganj area and represents a chunk of about 300-year old near-climax forest patch spread over 8.16-acre land. The Sufi saint Syed Shah Murshed Ali Al Kadri (believed to be an offspring of Hazarat Mohammed) was born on July 16, 1852 in Midnapore town and stayed and practiced religious rituals in a twin mosque area which is one of the historically famous mosques in Midnapore town. After his death on February 17, 1901 his mortal body was buried in the said mosque beside his father's burial ground.

It was reported that the saint was so upset after his 23-years old son's (Syed Shah Arshad Ali Al Kadri) death that he started meditation inside the present sacred grove for 12-years and finally attained sainthood. Since 1902, every year on his demise day, on 16 - 17 February, the Urs-Pak festival has been celebrated as a tribute to his holiness, around the twin mosque. When Muslim people from different corners of West Bengal in general and Bangladesh, in particular, visit the mosque and the sacred grove to have a view of his Holy Mazar (burial tomb) and divine blessings (Figure 2). The festival completed its 117 th year on 17 February, 2018, in which approximately 4000 people from Bangladesh, and 50,000 people from West Bengal participated. Muslim community considers the twin mosque-premises and the sacred grove as one of the holiest places in India. During the Urs-Pak festival, devotees pray to the saint and seek blessing and well-being. Presently, the entire grove is maintained and managed by the descendants of the saint. The present stakeholders have erected mechanical fencing in and around the sacred forest. They have introduced some sociocultural valuable plant species inside the grove. The whole geographical area along with its biotic and abiotic components is held sacred. There is a social prohibition on cutting and uprooting any plant specimen and even lifting plant litter from the grove is a taboo.

\section{Field survey and data collection}

The study area was thoroughly surveyed during the period from September 2015 to October 2018 in different seasons to study the botanical and social perspectives. Floristic surveys were carried out through "spot identification" basis. For unknown plants, samples of plants with flowers or fruits were collected. After collection, the specimens were processed, preserved, poisoned and mounted on herbarium sheets following the standard and modern herbarium techniques [19]. Photographs of some common, locally rare, endemic and valuable plant species in the sacred grove were taken. The herbarium sheets were identified by matching with correctly annotated materials available at the Herbarium of Vidyasagar University. For identification purpose, different relevant catalogue [20], regional floras [21-25], monographs [26], revision works [27] and other literature were consulted. The socio-cultural functions surrounding the grove were recorded through information collected by interviewing and cross-interviewing the devotees and local people during Urs-Pak festival.

\section{Analysis of vegetation}

In the systematic enumeration of the taxa; clade, order, family, species along with voucher number, habit, life-span, flowering and fruiting time, Raunkiaer's life-form with sub-type, leaf spectra and IUCN red list status [28] and distribution of the plants in the grove were arranged according to Angiosperm Phylogeny Group IV classification [29] (Table 1 [Appendix 1]). An additional summarized table showing a total number of orders, families, genera, and species under dicots and monocots was prepared (Table 2). All the species were categorized into various Raunkiaer's life form categories depending on the position of regenerating parts or propagules in all the collected species, and a biological spectrum was prepared for the grove, that was subsequently compared with the Raunkiaer's normal spectrum to determine the phytoclimate of the grove [9 - 11] (Table 1 [Appendix 1] and Table 3). The knowledge of leaf size helped us understand the physiological development of plants and the plant communities were useful in classifying the associations of 


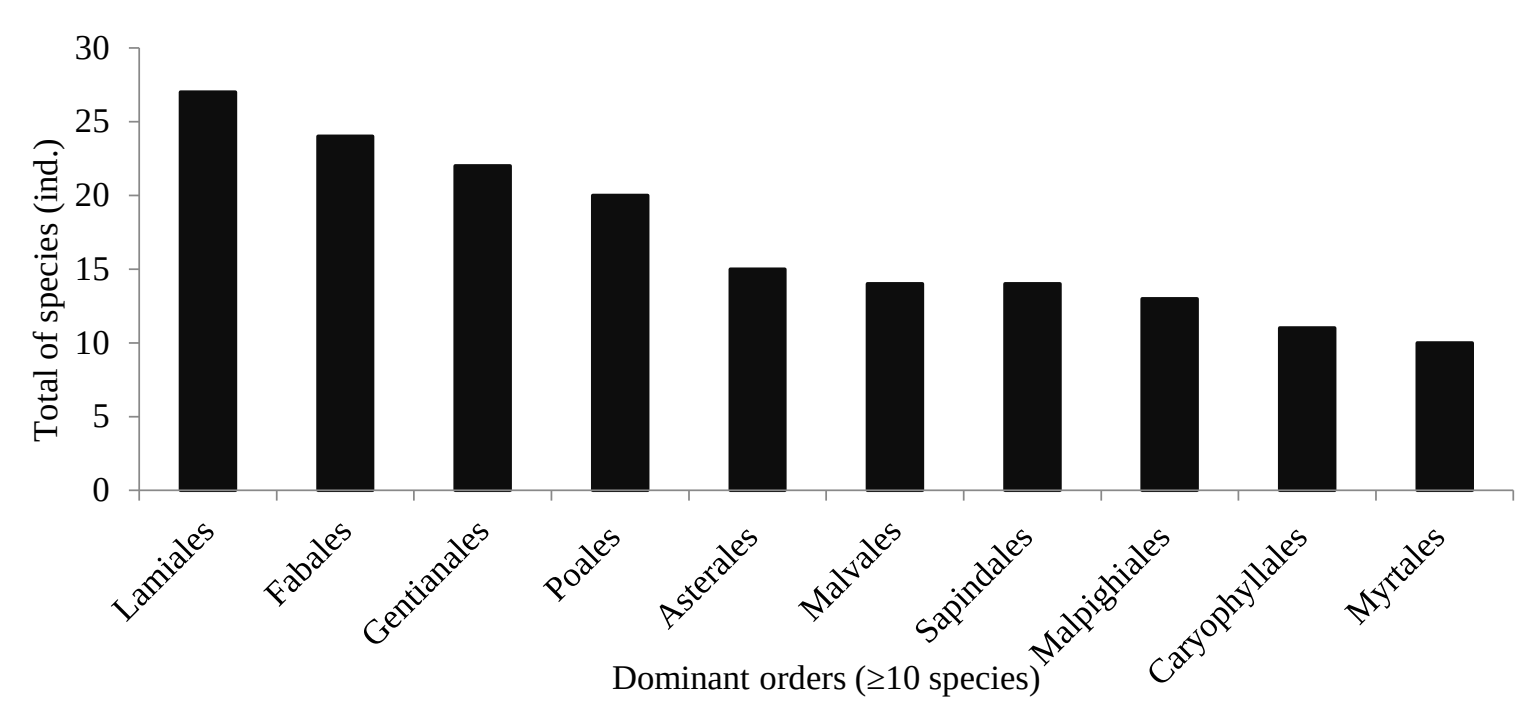

Figure 2. Major contribution of orders ( $\geq 10$ species) in the NBA

Table 2. Total angiosperm taxa

\begin{tabular}{cccccccccc}
\hline \multirow{2}{*}{ Group } & \multirow{2}{*}{ Orders } & \multirow{2}{*}{ Families } & \multirow{2}{*}{ Genera } & \multicolumn{5}{c}{ Species } \\
\cline { 5 - 9 } & & & & Herbs & Shrubs & Trees & Climber & Total \\
\hline Dicots & 23 & 57 & 191 & 69 & 57 & 65 & 33 & 224 \\
Monocots & 13 & 20 & 47 & 37 & 3 & 7 & 6 & 53 \\
Total & 36 & 77 & 238 & 106 & 60 & 72 & 39 & 277 \\
\hline
\end{tabular}

plants. Different plant leaf sizes were arranged with their respective Raunkiaer's life forms (Table 4). Plants were divided into (a) leptophyll $(<25$ $\mathrm{mm}^{2}$ ), (b) nanophyll (25 - $\left.225 \mathrm{~mm}^{2}\right)$, (c) microphyll (225 - 2,025 mm $\mathrm{mm}^{2}$, (d) notophyll (2,025 4,500 $\mathrm{mm}^{2}$ ), (e) mesophyll (4,500 - 18,225 $\mathrm{mm}^{2}$ ), (f) macrophyll $\left(18,225-164,025 \mathrm{~mm}^{2}\right)$ and (g) megaphyll (> 164,025 mm²) [9].

\section{Results and Discussion Different plant taxa}

In the present study, a total of 277 species belonging to 238 genera distributed over 77 families under 36 orders were recorded from the sacred grove according to the APG IV (2016) classification. The top two clades were Rosids and Asterids. More than $80 \%$ of the flora was represented by orders of Eudicot and Core Eudicot, of which the major contributions in terms of descending species number ( $\geq 10$ species) were from Lamiales 27 (9.75\%), Fabales 24 (8.66\%), Gentianales 22 (7.94\%), Poales 20 (7.22\%), Asterales 15 (5.42\%), Malvales 14 (5.05\%), Sapindales 14 (5.05\%), Malpighiales 13 (4.69\%), Caryophyllales 11 (3.97\%) and Myrtales 10 (3.61\%) (Table 1 [Appendix 1]). Similar types of distribution of orders were highlighted by Mygatt and Medeiros [30]; Gastauer et al. [31] (Table 1 [Appendix 1] and Figure 2).

The ten well represented families in species ( $\geq$ 7 species), quantity were: Fabaceae 32 (11.55\%), Malvaceae 18 (6.50\%), Poaceae 18 (6.50\%), Asteraceae 15 (5.42\%), Apocynaceae 14 (5.05\%), Lamiaceae 14 (5.05\%), Acanthaceae 9 (3.25\%), Euphorbiaceae 9 (3.25\%), Rubiaceae 8 (2.89\%), and Cyperaceae 7 (2.53\%) (Figure 3). Whereas two families contained 6 (2.17\%), four families contained 5 (1.81\%), five families contained 4 (1.44\%), six families contained $3(1.08 \%)$ and thirteen families comprised $2(0.72 \%)$ species each respectively. Another 37 families each carried only a single species (Table 1 [Appendix 1]). Same type dominant families of sacred groves in India were observed by Rajendraprasad et al. [32]; Jamir et al. [33]; Ghildiyal et al. [34]; Sen [17] etc. In the global context, such family dominance was shown by Batalha and Martins [35]; Badshah et al. [36]; Chigani et al. [37] etc.

The ten dominant plant families encompassed more than $50 \%$ genera with descending numbers ( $\geq 5$ species) were Fabaceae 24 (10.04\%), Poaceae 17 (7.11\%), Asteraceae 15 (6.28\%), Apocynaceae 


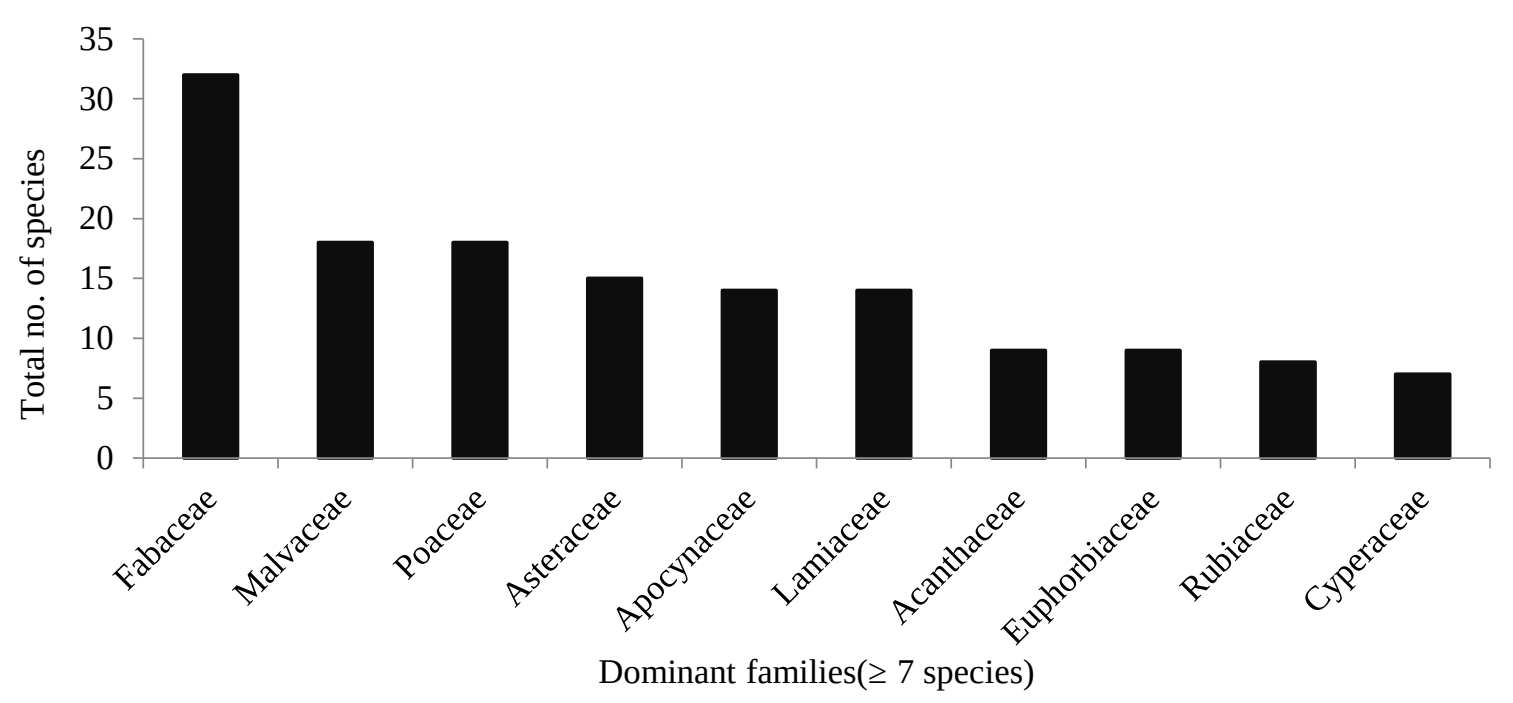

Figure 3. Major contribution of families ( $\geq 7$ species) in the NBA

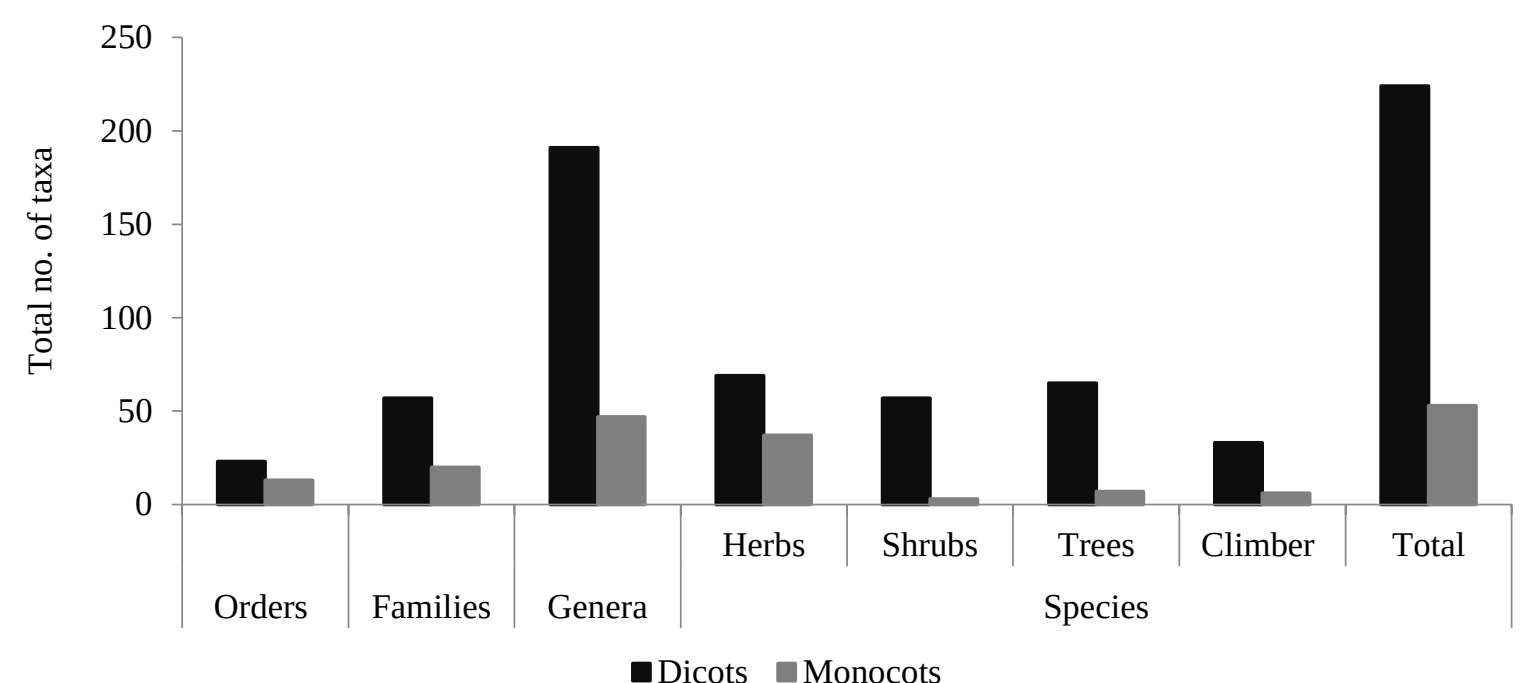

Figure 4. Total angiosperm taxa

14 (5.86\%), Malvaceae 14 (5.86\%), Lamiaceae 12 (5.02\%), Acanthaceae 8 (3.35\%), Rubiaceae 7 (2.93\%), Euphorbiaceae 6 (2.51\%) and Amaranthaceae 5 (2.09\%) (Table 1 [Appendix 1]).

Genus Cyperus comprises four species; whereas three species containing genera were Acacia, Bauhinia, Euphorbia, Ficus, Ocimum, Senna, Sida, Solanum, and Terminalia. The sixteen well-represented genera containing two species were Albizia, Amaranthus, Annona, Cleome, Combretum, Crotalaria, Datura, Eragrostis, Fimbristylis, Gardenia, Hibiscus, Jatropha, Justicia, Phyllanthus, Trichosanthes, and Ziziphus. Another 214 species belong to a single genus respectively (Table 1 [Appendix 1]).

\section{Species diversity in different growth form}

The present floristic study of the sacred grove showed that it harbored a total of 277 plant species [dicots 224 (80.87\%) and monocots 53 (19.13\%)] belonging to genera 238 [dicots 191 (80.25\%) and monocots $47(19.75 \%)$ ] of 77 families [dicots 57 (74.03\%) and monocots 20 (25.97\%)] under 36 orders [dicots 23 (63.89\%) and monocots 13 (36.11\%)]. Among these, 106 (38.27\%) of the reported species were herbs. Other reported species were shrubs 60 (21.66\%), trees 72 (25.99\%) and climbers 39 (14.08\%) respectively. Amongst the total dicots 123 (82\%) and monocots 27 (18\%), herbs, shrubs, trees and climbers represented 69, 57, 65, 33 and 37, 3, 7, 6 species respectively, representing $24.91 \%, 20.58 \%, 23.47 \%, 11.91 \%$ and 


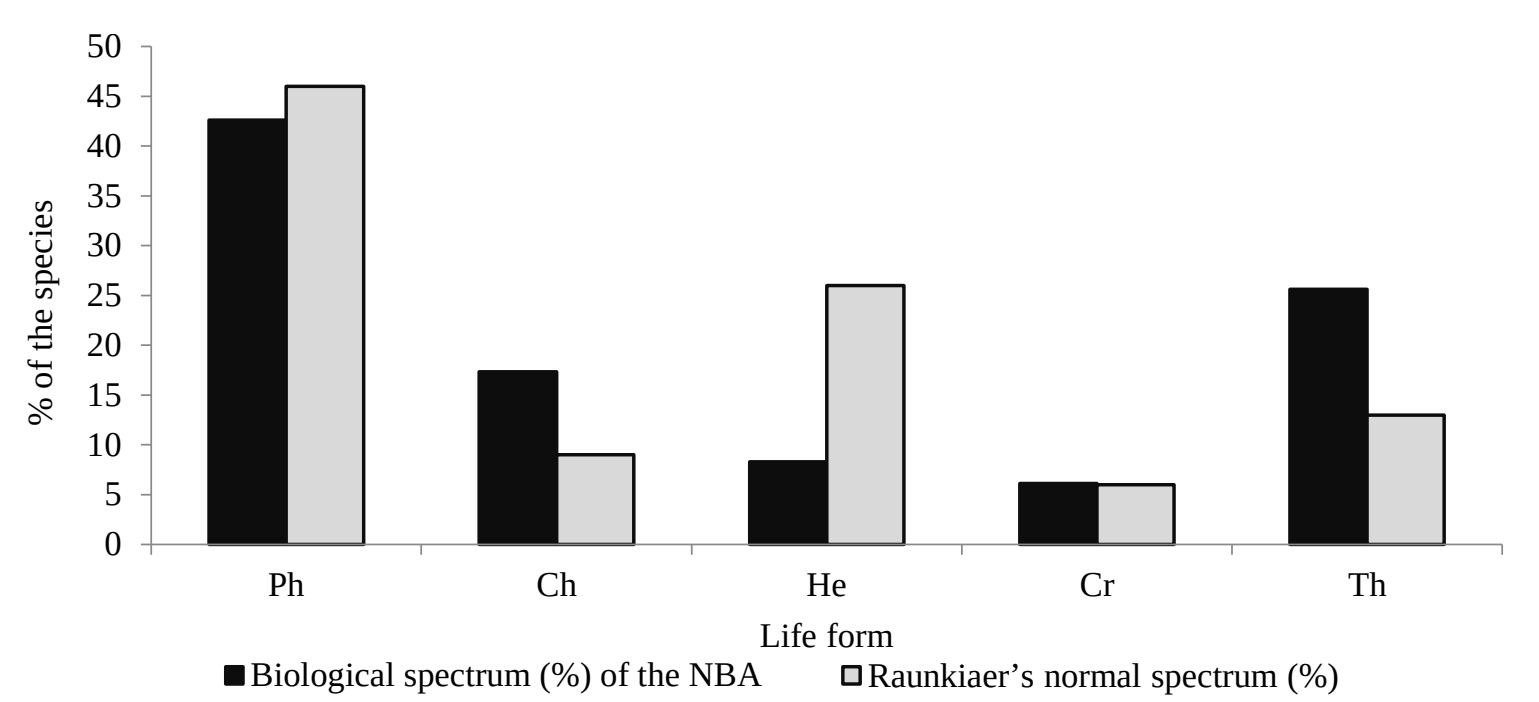

Figure 5. Comparison of Biological spectrum with Raunkiaer’s normal spectra

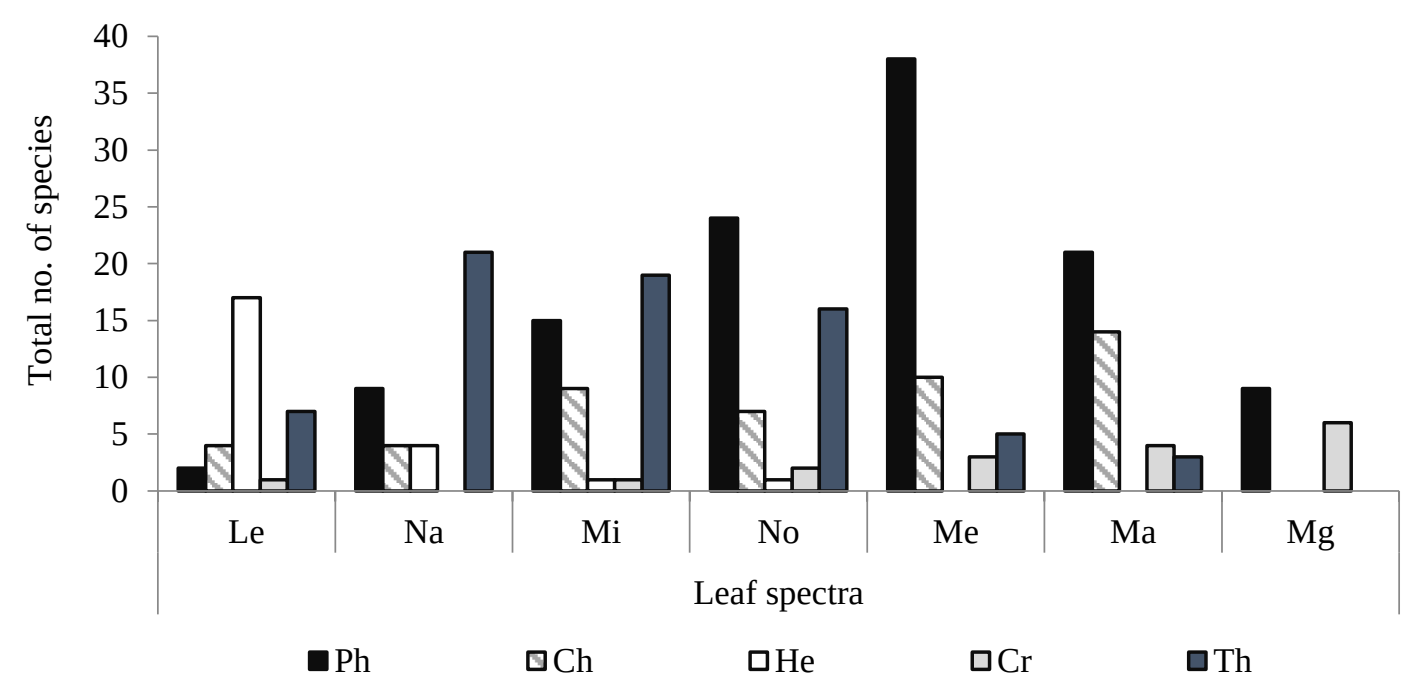

Figure 6. Major contribution of families ( $\geq 7$ species) in the NBA (Ph: phanerophytes, Ch: chamaephytes, Cr: cryptophytes, He: hemicryptophytes, and Th: therophytes)

$13.36 \%, 1.08 \%, 2.53 \%, 2.17 \%$ of the total species (Table 2 and Figure 4).

\section{Life span}

In the sacred grove, 96 (34.66\%) annual plants would go through their life cycle in one growing season. As many as $1(0.36 \%)$ biennial plant whose life cycle spans two years. As many as 180 (64.98\%) perennial plants that could survive most unfavorable conditions and stayed alive for more than two years (Table 1 [Appendix 1]).

\section{Life form and biological spectrum}

The biological spectrum shows that phanerophytes 118 (42.60\%) was the dominant, followed by therophytes 71 (25.63\%), chamaephytes 48
(17.33\%), hemicryptophytes 23 (8.30\%), and cryptophytes 17 (6.14\%). of the phanerophytes, nanophanerophytes 66 (23.83\%) was dominant than mesophanerophytes 28 (10.11\%) and megaphanerophytes 24 (8.66\%) (Table 3 and Figure 5). It reveals that therophytes, chamaephytes, and cryptophytes constituted the higher percentage $12.63 \%, 8.33 \%$ and $0.14 \%$ respectively than the normal spectrum exhibiting "thero-chamae-cryptophytic" phytoclimate.

Further, the number of hemicryptophytes (17.7\%) and phanerophytes (3.4\%) was comparatively smaller in percentage than the Raunkiaer's normal spectrum. Of the phanerophytes, nanophanerophytes (8.83\%) and megaphanerophytes (5.66\%) were somewhat larger and mesophanero- 
phyte (17.89\%) was a comparatively smaller value than the Raunkiaer's normal spectrum (Table 3). This result was probably due to the local protection under certain taboos of the sacred grove. The dominant therophytes, chamaephytes, and cryptophytes altogether constituted $49.1 \%$ of the life forms proportion. Therophytes showed the maximum divergence of the normal spectrum; other workers had also reported a similar phytoclimatic association for different tracks of vegetation [38, 12, 32, 39]. The dominance of therophytes (71 species, 25.63\%) indicates that the investigated area was under mild biotic pressure. Many plant species were decreasing in the area. It would be the moral and ethical duty of the local people to protect the plant resources.

\section{Leaf size spectra}

The overall leaf size spectra showed that there were leptophyll 31 (11.19\%), nanophyll 38 (13.72\%), microphyll 45 (16.24\%), notophyll 49 (17.69\%), mesophyll 56 (20.22\%), macrophyll 43 (15.52\%) and megaphyll 15 (5.42\%). As regards the leaf size spectra, mesophyll was found to be high followed by notophyll, microphyll, macrophyll, nanophyll, leptophyll, and megaphyll (Table 1 [Appendix 1]).

In case of leaf spectra, the presence of leptophyll 17 (6.14\%), nanophyll 21 (7.58\%), microphyll 19 (6.86\%), notophyll 24 (8.66\%), mesophyll 38 (13.72\%), macrophyll 21 (7.58\%) and megaphyll 9 (3.25\%) have the maximum in comparison to hemicryptophytes, therophytes, chamaephytes, cryptophytes, and phanerophytes respectively (Table 4 dan Figure 6).

Poaceae 11 (3.97\%), Fabaceae 9 (3.25), Fabaceae 8 (2.89\%), Apocynaceae 7 (2.53\%), Malvaceae $6(2.17 \%)$, Malvaceae $6(2.17 \%)$, and Araceae $3(1.08 \%)$ were dominant families of leptophyll, nanophyll, microphyll, notophyll, mesophyll, macrophyll and megaphyll respectively (Table 1 [Appendix 1]). This result was also similar to other tropical forests in Asia [40, 18].

\section{Conservation status and IUCN categories}

Among these 277 plant species, 226 plants have not been evaluated still now. There were 45 Least Concerned (LC), 1 Vulnerable (VU), 2 Endangered (EN), 1 Lower Risk/ Least Concerned (LR/LC) and 2 Data Deficient (DD) species. Borassus flabellifer and Swietenia mahagoni were
Table 3. Biological spectrum (\% of all life forms) of sacred grove and its comparison with Raunkiaer's normal spectrum

\begin{tabular}{ccccc}
\hline $\begin{array}{c}\text { Raun- } \\
\text { kiaer's } \\
\begin{array}{c}\text { Life } \\
\text { forms }\end{array}\end{array}$ & $\begin{array}{c}\text { Total } \\
\text { no. of } \\
\text { species }\end{array}$ & $\begin{array}{c}\text { Biologi- } \\
\text { cal spec- } \\
\text { trum (\%) } \\
\text { of the } \\
\text { NBA }\end{array}$ & $\begin{array}{c}\text { Raun- } \\
\text { kiaer's } \\
\text { normal } \\
\text { spectrum } \\
(\%)\end{array}$ & $\begin{array}{c}\text { Deviation= } \\
\text { (Raunkiaer's } \\
\text { normal spec- } \\
\text { trum- Biologi- } \\
\text { cal spectrum) }\end{array}$ \\
\hline Ph & 118 & 42.60 & 46.00 & -3.4 \\
$M M$ & 24 & 8.66 & 3.00 & 5.66 \\
$M$ & 28 & 10.11 & 28.00 & -17.89 \\
$N$ & 66 & 23.83 & 15.00 & 8.83 \\
Ch & 48 & 17.33 & 9.00 & 8.33 \\
He & 23 & 8.30 & 26.00 & -17.7 \\
Cr & 17 & 6.14 & 6.00 & 0.14 \\
Th & 71 & 25.63 & 13.00 & 12.63 \\
Total & 277 & 100 & 100 & 0 \\
\hline
\end{tabular}

Table 4. Life-form analysis with different leaf size

\begin{tabular}{lcccccccc}
\hline \multirow{2}{*}{$\begin{array}{c}\text { Raunkiaer's life } \\
\text { form }\end{array}$} & \multicolumn{9}{c}{ Leaf spectra } \\
\cline { 2 - 8 } & Le & Na & Mi & No & Me & Ma & Mg & \\
\hline $\mathrm{Ph}$ & 2 & 9 & 15 & 24 & 38 & 21 & 9 & 118 \\
$M M$ & 0 & 1 & 2 & 0 & 7 & 11 & 3 & 24 \\
$M$ & 0 & 4 & 3 & 8 & 7 & 5 & 3 & 28 \\
$N$ & 2 & 4 & 10 & 15 & 24 & 6 & 3 & 65 \\
$\mathrm{Ch}$ & 4 & 4 & 9 & 7 & 10 & 14 & 0 & 48 \\
$\mathrm{He}$ & 17 & 4 & 1 & 1 & 0 & 0 & 0 & 23 \\
$\mathrm{Cr}$ & 1 & 0 & 1 & 2 & 3 & 4 & 6 & 17 \\
$\mathrm{Th}$ & 7 & 21 & 19 & 16 & 5 & 3 & 0 & 71 \\
Total & 31 & 38 & 45 & 49 & 56 & 43 & 15 & 277 \\
\hline
\end{tabular}

the endangered tree species; whereas Santalum album was the vulnerable tree species according to the IUCN [28] (Table 1 [Appendix 1]).

Because of the above phytosociological analysis with ecological information about IUCN Red Listed plants reveals that the plants were still present and regenerate in the sacred grove but locally vanishing in nearby forests. This study would highlight the status and distribution of the species in the study area, the ecological characteristics necessary for its survival and the threats faced by some of the species designated by following the criteria devised by IUCN [28]. Various factors caused the increase in numbers of threatened species in the area. Grazing was a major cause which led to the destruction of seedlings. In contrast, restricted population and low natural reproduction were determined to be the factors most effective on the vulnerability of Santalum album. The most critical factor that caused the decline of this species was a human activity, such as pilgrimage, dying of the plant and land use change. 


\section{Conclusion}

The present study denotes the possibility of the utilization of Raunkiaer's approach to ascertain the remarkable distinctions between the angiosperm plant communities in a forested landscape or biome and their associations, portion of species in floristic life forms proportion which led by the existing ecological parameters and environmental gradients. Analysis of life forms gives a clear picture of the biological spectrum of the sacred grove. In the present study both therophytes, chamaephytes, and cryptophytes share the importance depicting the "thero-chamae-cryptophytic" phytoclimate. This study may thus be helpful to compare and contrast the adjacent natural vegetation along the environmental gradients, revealing more ecosystem information than the mere forest cover. It also suggests that the biotic factors play important role to shape the vegetation of a landscape by directing succession. This indicates the influence of anthropogenic disturbance in the sacred grove which favors the growth of more therophytes.

\section{Acknowledgment}

The authors are indebted to the informants and local Muslim communities for cooperating and sharing their knowledge. Without their contribution, this study would have been impossible.

\section{References}

1. Kent EF (2013) Sacred groves and local gods: religion and environmentalism in South India. Oxford University Press, Oxford. doi: 10.1093/acprof:oso/9780199895465.001.0001.

2. Sinha RK (1995) Biodiversity conservation through faith and tradition in India: some case studies. The International Journal of Sustainable Development \& World Ecology 2 (4): 278 - 284. doi: 10.1080/13504509509469908.

3. Colding J, Folke C (2001) Social taboos: “invisible” systems of local resource management and biological conservation. Ecological Applications 11 (2): 584 - 600. doi: 10.1890/10510761(2001)011[0584:stisol]2.0.co;2.

4. Khan ML, Khumbongmayum AD, Tripathi RS (2008) The sacred groves and their significance in conserving biodiversity: An overview. International Journal of Ecology and Environmental Science 34 (3): 277 - 291.

5. Verschuuren B, Wild R, McNeely J, Oviedo G, eds. (2010). Sacred natural sites conserving nature and culture. Washington, DC., Earthscan.

6. Bhakat RK, Sen UK (2013) Conservation value of a sacred grove. Indian Journal of Forestry 36 (2): 217-226.
7. Bhakat RK, Sen UK (2017) Sacred groves: Traditional plant conservation through deities. In: Bandopadhyay (Mukhopadhyay) S, Hens DK, De PS, eds. Plants the natural wonder: Challenges and avenues. Burdwan, Damodar group. Pp 211-224.

8. Cain SA, Castro GDO (1959) Manual of vegetation analysis. New York, Harper and Brothers.

9. Raunkiaer C (1934) The life forms of plants and statistical plant geography. Oxford, Clarendon Press.

10. Cain SA (1950) Life-form and phytoclimates. Botanical Review 16 (1): $1-32$.

11. Muller D, Ellenberg H (1974) Aims and methods of vegetation ecology. New Jersey, The Blackburn Press.

12. Saxena AK, Pandey P, Singh JS (1982) Biological spectrum and other structural functional attributes of the vegetation of Kumaun Himalaya. Vegetatio 49 (2): 111 - 119. doi: 10.1007/bf00052766.

13. Meher-Homji VM (1964) Life forms and biological spectra as epharmonic criteria of aridity and humidity in tropics. The Indian Botanical Society 43: 424-430.

14. Rana TS, Datt B, Rao RR (2002) Life forms and biological spectrum of the flora of Tons Valley, Garhwal Himalaya (Uttaranchal), India. Taiwania 47 (2): 164 - 169.

15. Sen UK, Bhakat RK (2009) Ecological role of sacred groves in plant conservation. In: Sinha TRC, ed. Effects of environmental toxicology on human health. New Delhi, NESA. Pp $211-219$.

16. Sen UK, Bhakat RK (2012) Sacred grove and plant conservation: An insight from taxonomy and ecology. In: Maiti GG, Mukherjee SK, eds. Mutidisciplinary approaches in angiosperm systematics. Kalyani, Department of Botany, University of Kalyani. Pp 410-421.

17. Sen UK (2016) Botanical and socio-cultural studies on some sacred groves of West Midnapore district, West Bengal. Ph.D. Thesis. Vidyasagar University, India.

18. Gillison AN (2018) Latitudinal variation in plant functional types. In: Greller AM, Fujiwara K, Pedrotti F, eds. Geographical changes in vegetation and plant functional types. Cham, Springer. Pp 21 - 57. doi: 10.1007/978-3-319-68738-4_2.

19. Jain SK, Rao RR (1977) A Handbook of field and herbarium methods. New Delhi, Today and Tomorrow's Printers and Publishers.

20. Anderson T (1862) Catalogue of plants indigenous in the neighborhood of Calcutta with directions for examination and preservation of plants. Calcutta.

21. Hooker JD (1872-1897) The flora of British India. Vol. I-VII. London, Reeve and Co.

22. Prain D (1903) Bengal plants. Vol. 1 \& 2. Botanical Survey of India, Calcutta.

23. Haines HH (1921-1925) The botany of Bihar and Orissa. Vol. 1-6. Botanical Survey of India, Calcutta.

24. Bennet SSR (1979) Flora of howrah district. Dehradun, International Book Distributors. 
25. Sanyal MN (1994) Flora of Bankura district. Dehradun, Bishen Singh Mahendra Pal Singh.

26. Mitra JN (1958) Flowering plants of eastern India. Vol. I, Monocotyledons. Calcutta, The World Press Private Ltd.

27. Datta SC, Majumdar NC (1966) Flora of Calcutta and vicinity. Bulletin of Botanical Society of Bengal 20: 16 - 120.

28. IUCN (2018) The IUCN Red List of Threatened Species. Version 2018-1. https://www.iucnredlist.org. Accessed date: 27 December 2018.

29. Chase MW, Christenhusz MJM, Fay MF et al. (2016). An update of the angiosperm phylogeny group classification for the orders and families of flowering plants: APG IV. Botanica Journal of Linnean Society 181 (1): 1 - 20. doi 10.1111/boj.12385.

30. Mygatt J, Medeiros J (2009) Lab manual to the flora of New Mexico. Albuquerque, University of New Mexico.

31. Gastauer M, Neto M, Alves JA (2017) Updated angiosperm family tree for analyzing phylogenetic diversity and community structure. Acta Botanica Brasilica 31 (2): 191 - 198. doi: 10.1590/0102-33062016abb0306.

32. Rajendraprasad M, Krishnan PN, Pushpangadan P (1998) The life form spectrum of sacred grove and a functional tool to analyse the vegetation. Tropical Ecology 39: 211-217.

33. Jamir SA, Upadhaya K, Pandey HN (2006) Life form composition and stratification of montane humid forests in Meghalaya, northeast India. Tropical Ecology 47 (2): 183 - 190.
34. Ghildiyal JC, Barthwal N, Khantwal A (2016) Life-forms and biological spectrum of Deeva Ka Daanda a sacred grove in Garhwal Himalaya. Indian Forester 142 (2): 167 - 178.

35. Batalha MA, Martins FR (2004) Floristic, frequency and vegetation life-form spectra of a cerrado site. Brazilian Journal of Biology 64 (2): 201 - 209. doi: 10.1590/S151969842004000200004.

36. Badshah L, Hussain F, Sher Z (2016) Floristic inventory, ecological characteristics and biological spectrum of plants of Parachinar, Kurram agency, Pakistan. Pakistan Journal of Botany 48 (4): 1547 - 1558.

37. Chigani HK, Javadi SA, Zahedi-Amiri G et al. (2017) Vegetation composition differentiation and species-environment relationships in the northern part of Isfahan Province. Land Degradation and Development 9 (2): 161 - 175. doi: 10.1007/s40333017-0050-2.

38. Misra MP, Mishra, PN, Pandey BN (1979) An ecological account of the vegetation of Brahmyoni Hills (Gaya). Proceedings of the Indian Science Congress 3: 108 - 109.

39. Sen UK (2018) Assessing the social, ecological and economic impact on conservation activities within human-modified landscapes: A case study in Jhargram District of West Bengal, India. International Journal of Conservation Science 9 (2): 319 - 336.

40. Bohman K (2004) Functional and morphological diversity of trees in different land use types along a rainforest margin in Sulawesi, Indonesia. Ph.D. Thesis. University of Gottingen, Gottingen. 

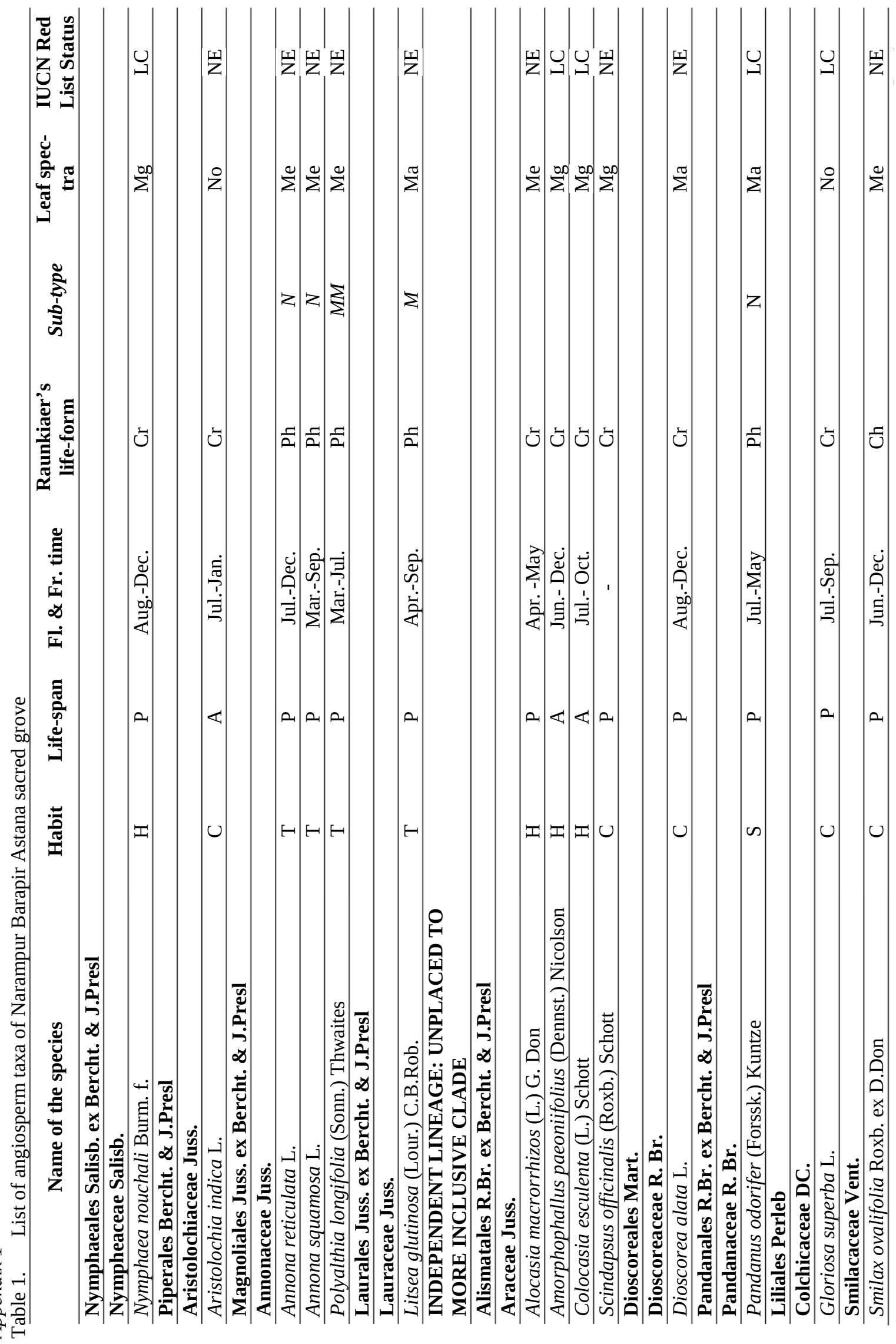


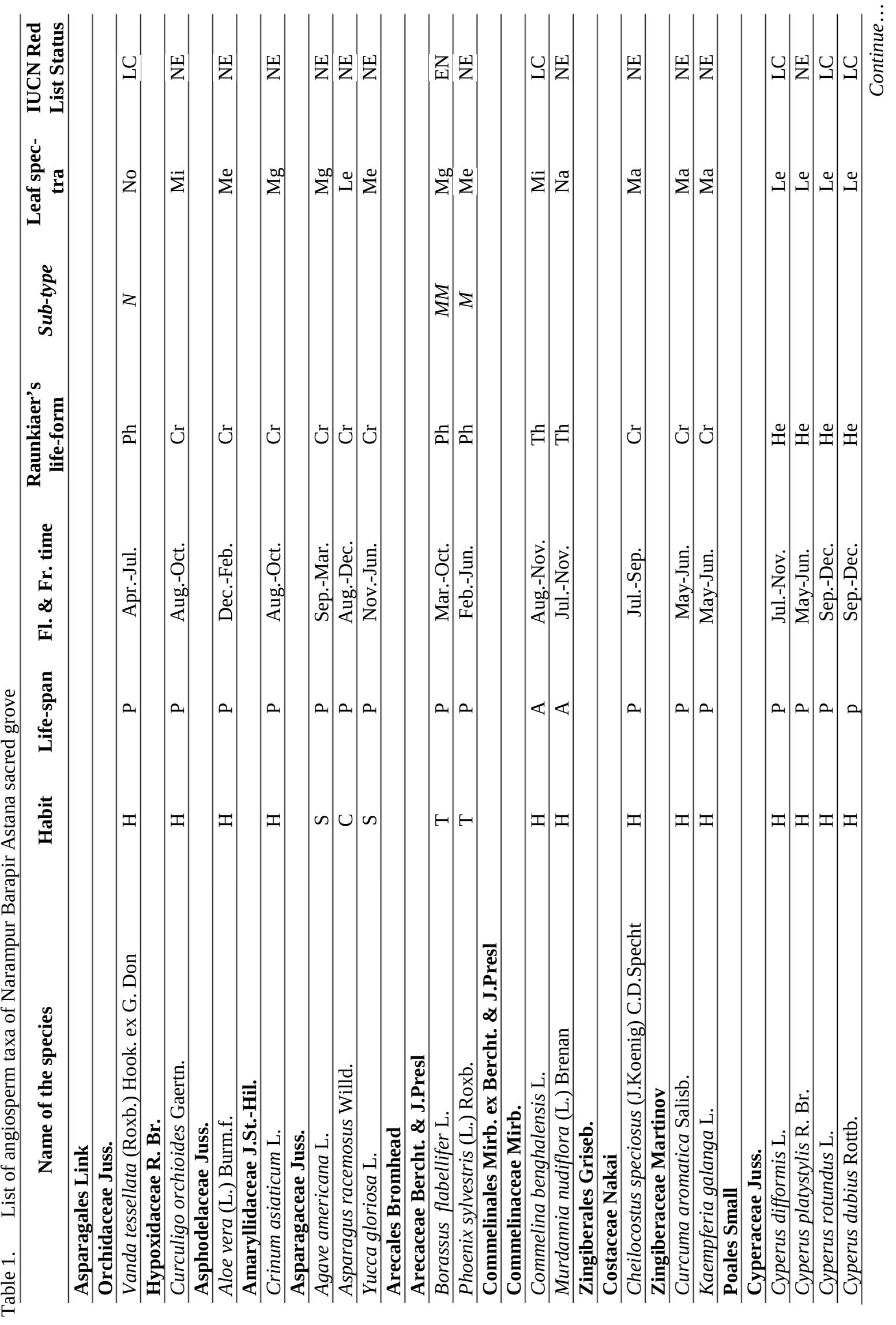




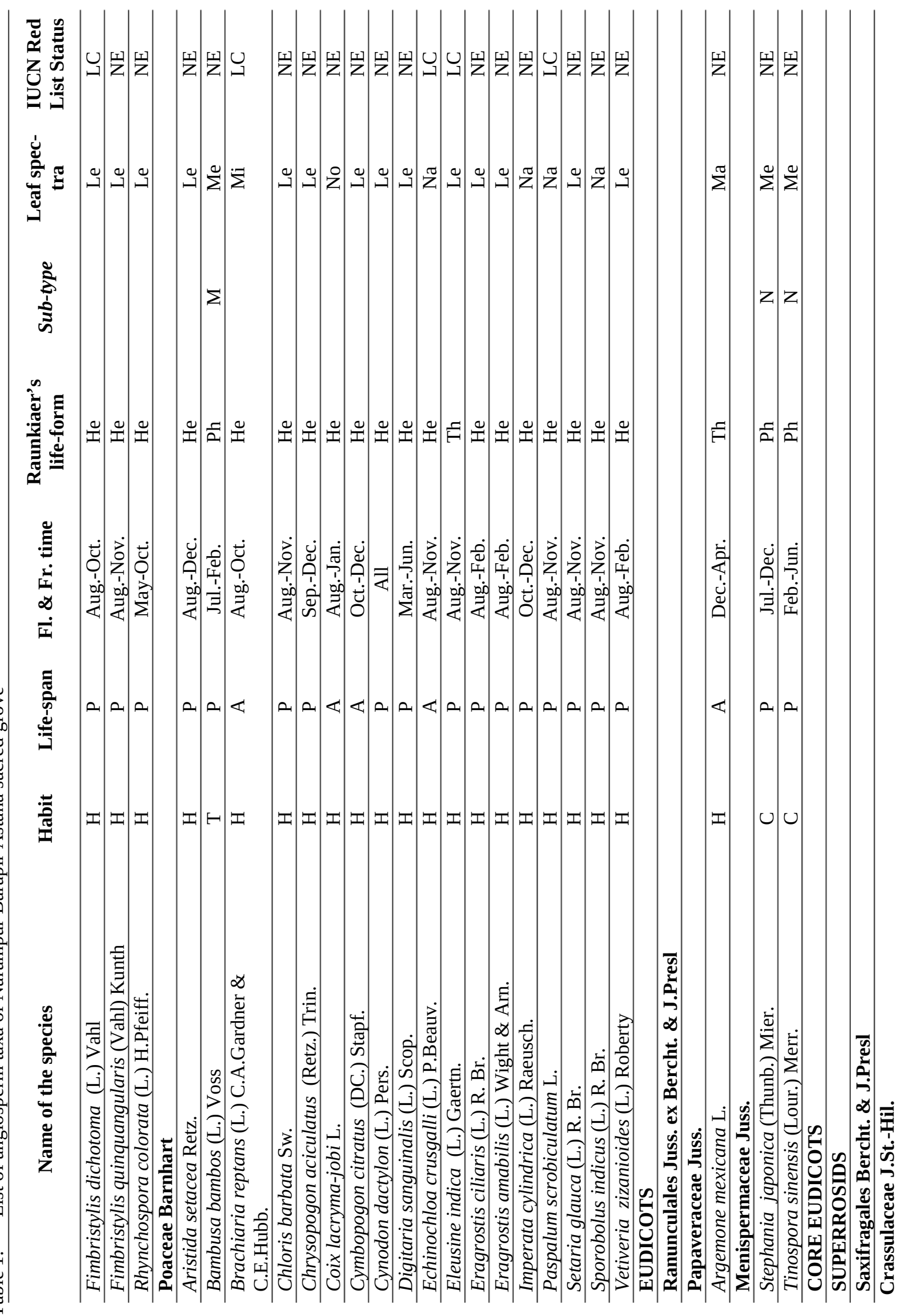




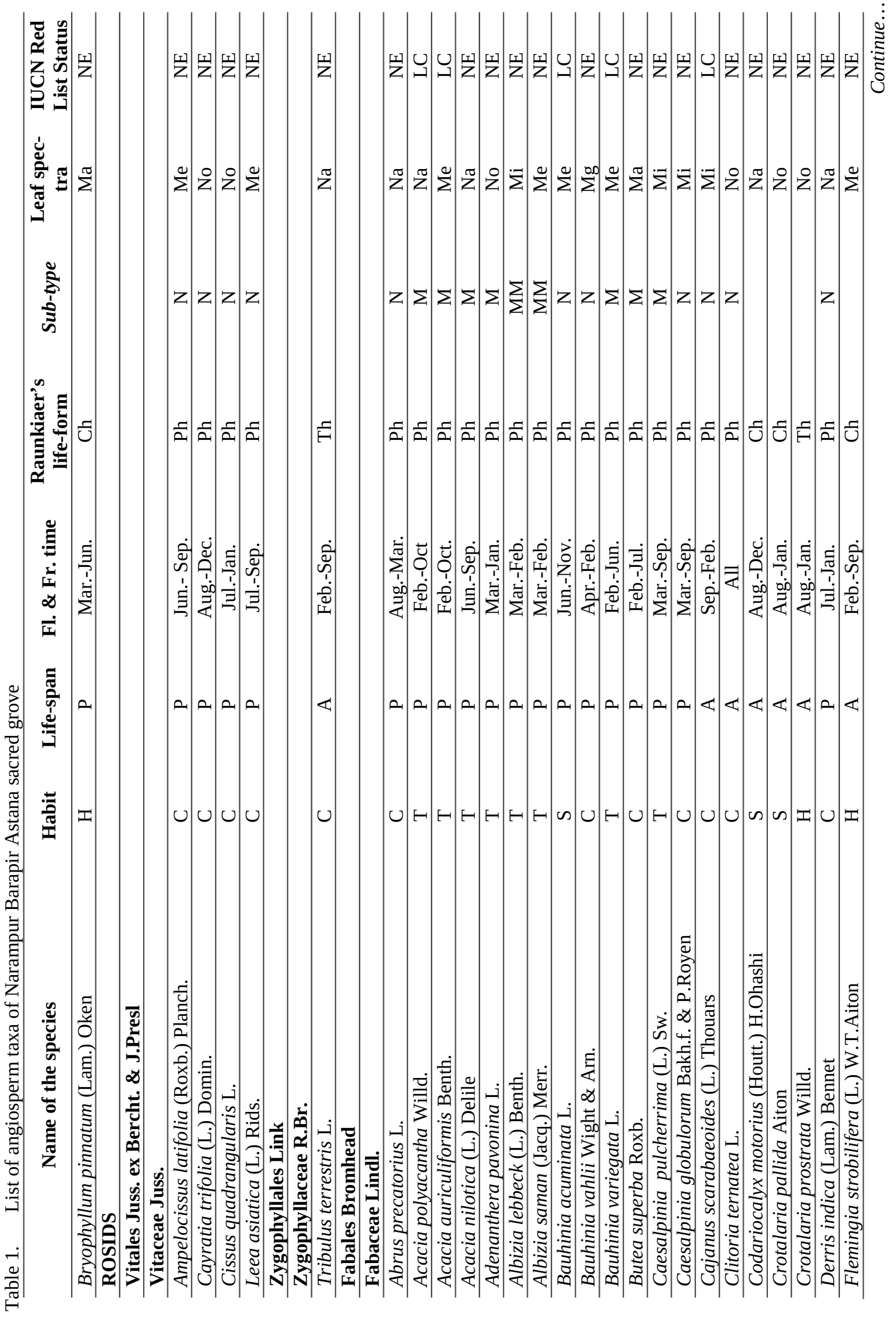




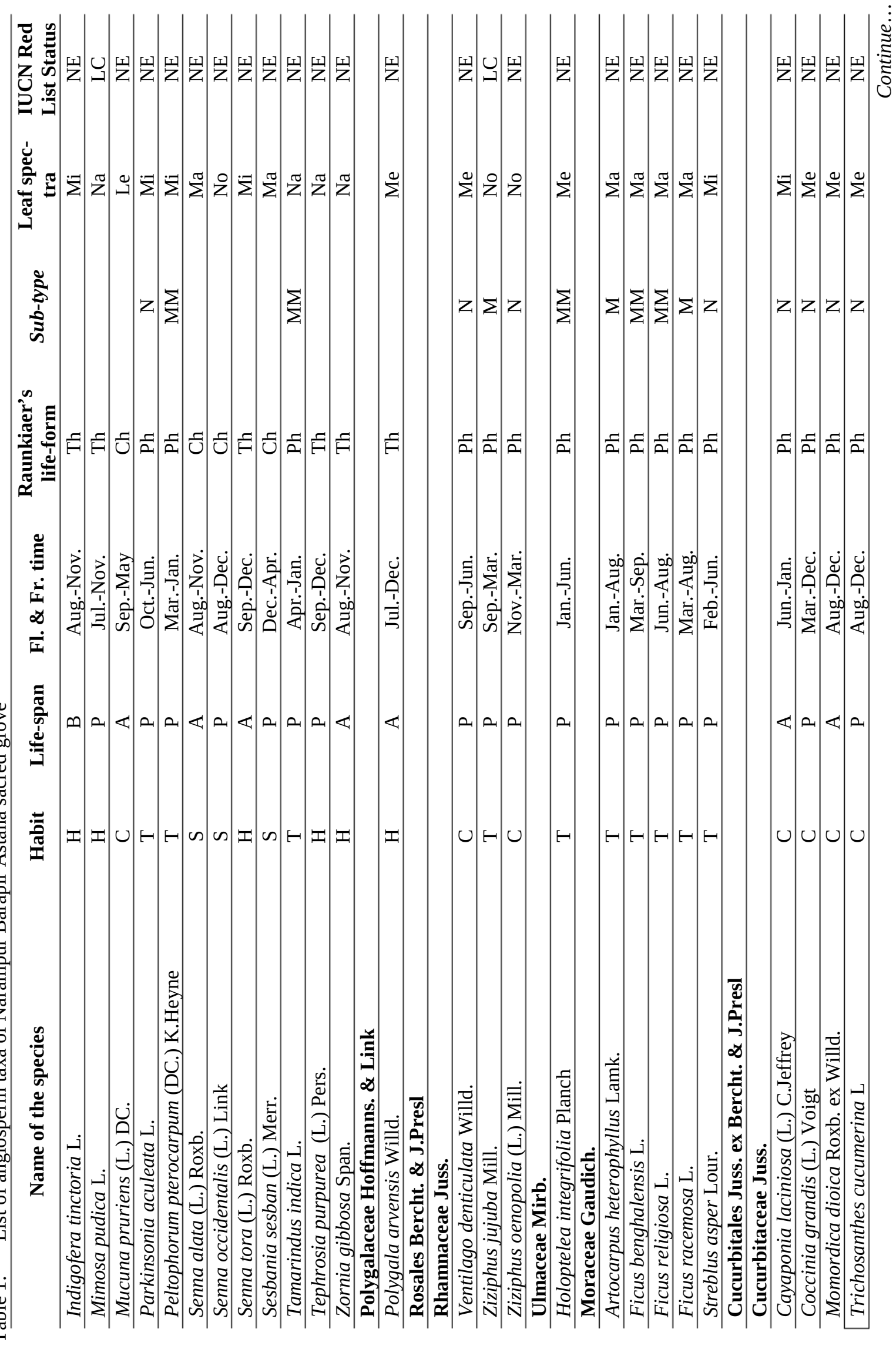




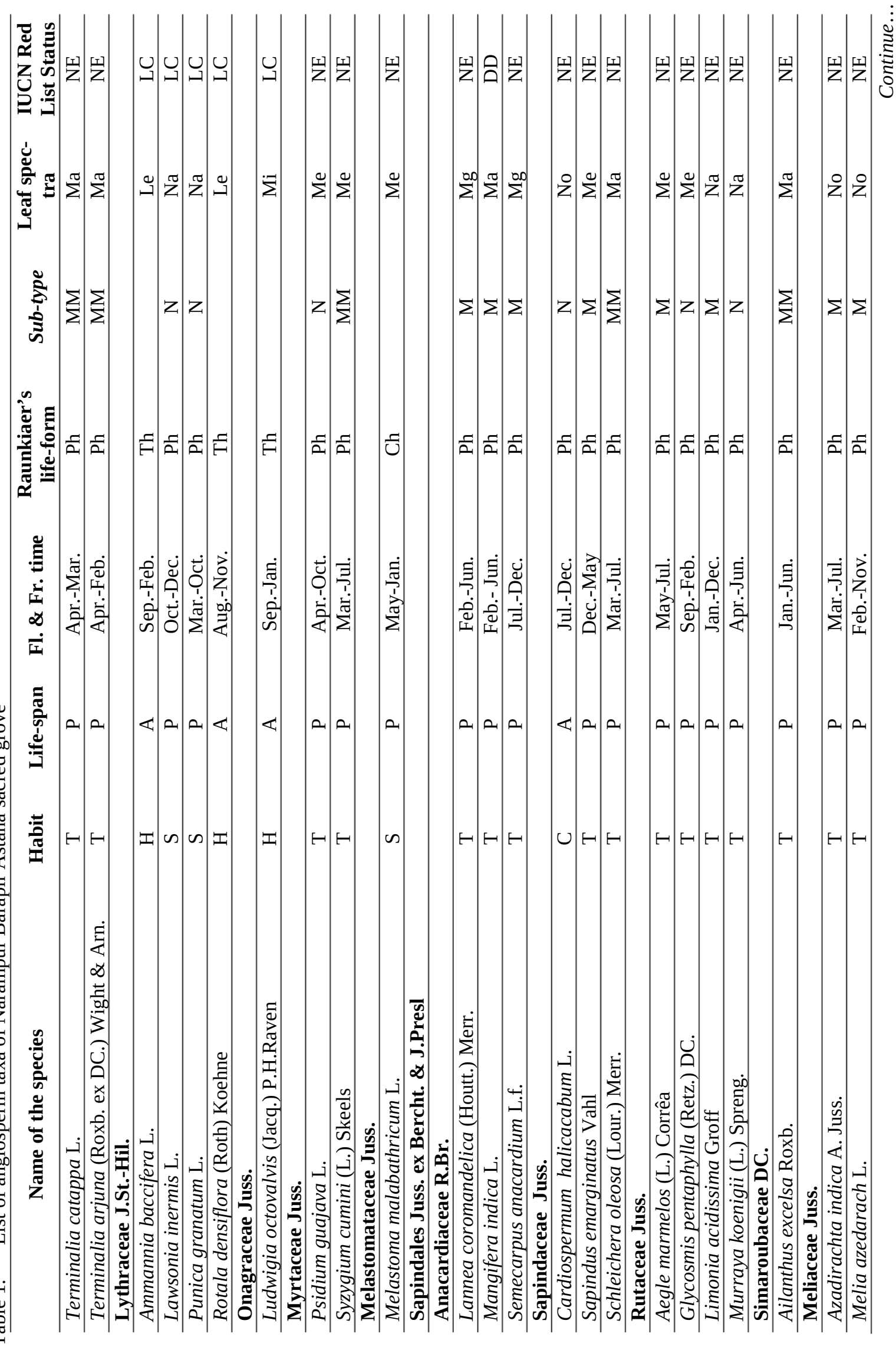




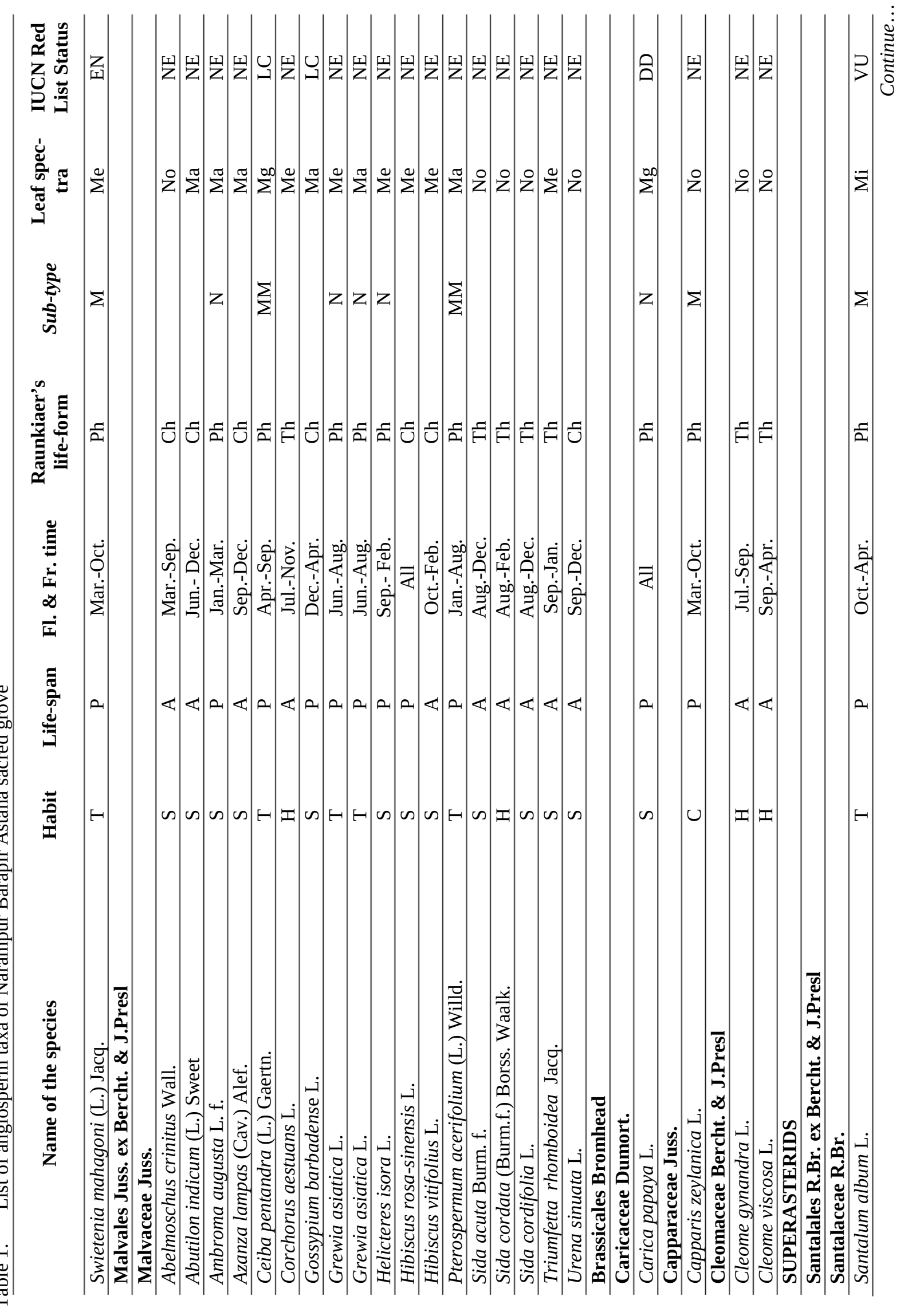




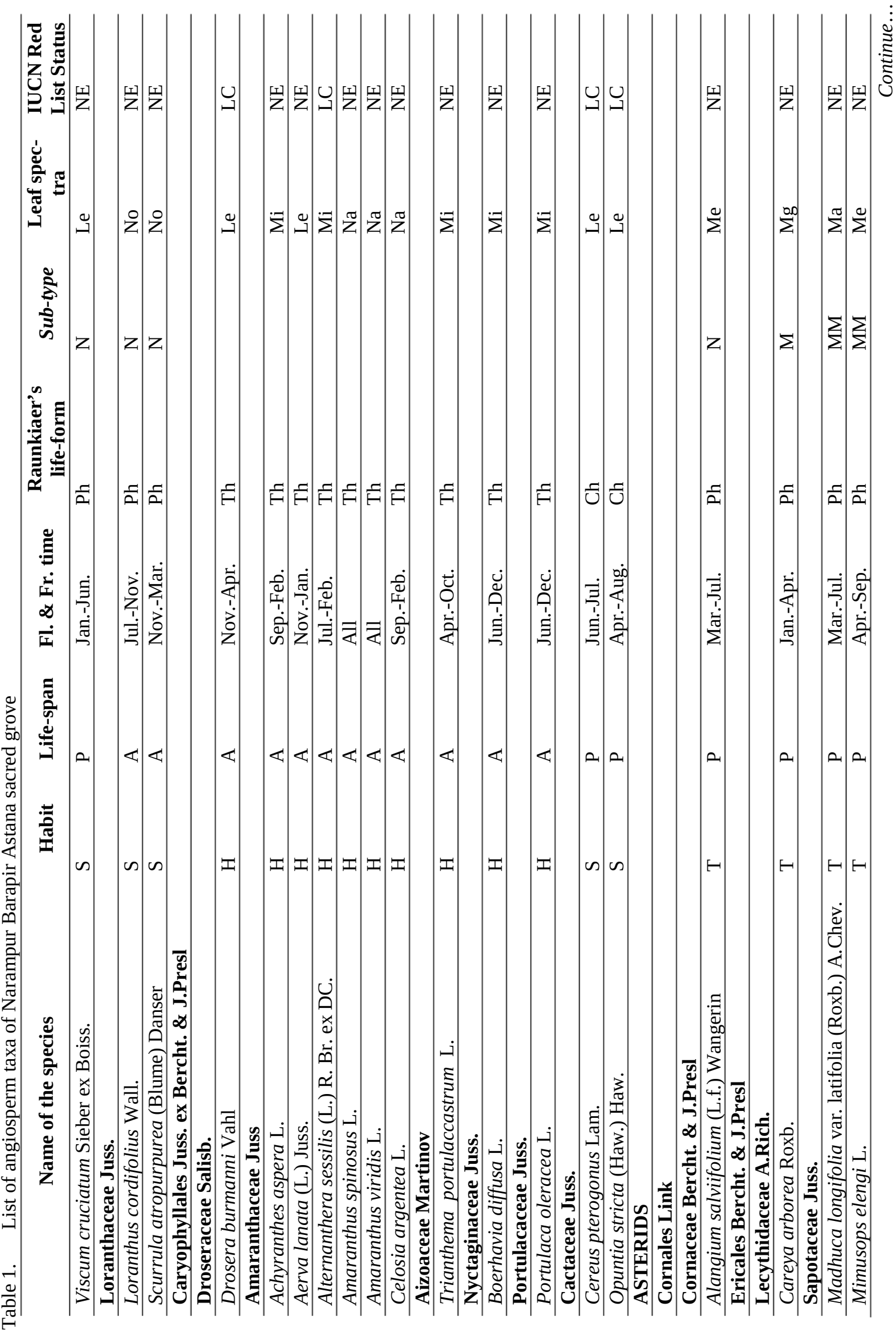




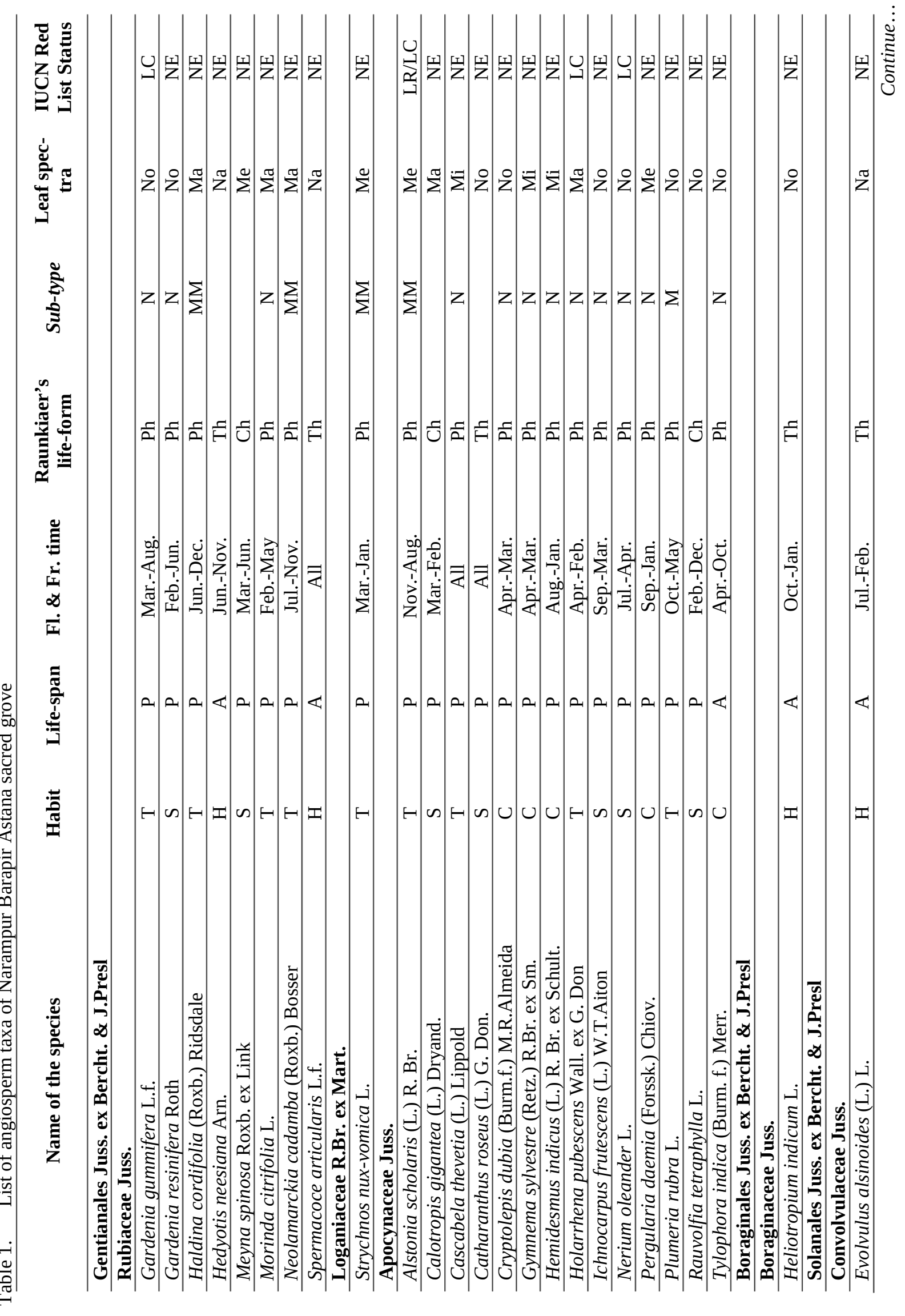




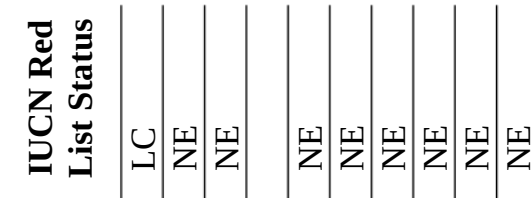

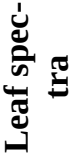

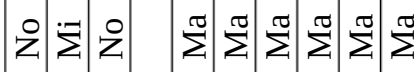

旁

के $z \mid z$

离

드로르 ปี

岁

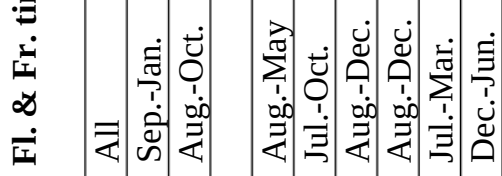

है

के

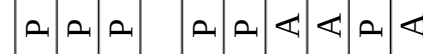

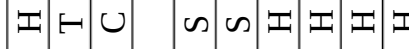

.

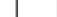

萦 表

닌

至

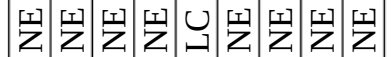

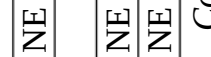

文

อิ

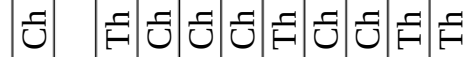

ㅎำ ปี ปี

:

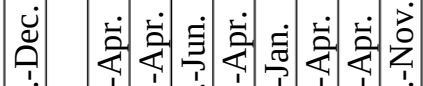

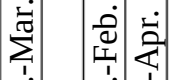

ஸे फें

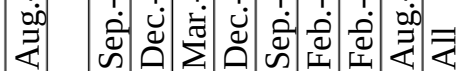

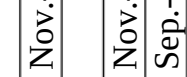

$\therefore \quad \varangle<$

$\varangle$

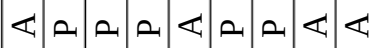

$\infty \quad \infty$

:

H I I I I I

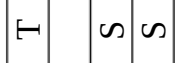

赔 


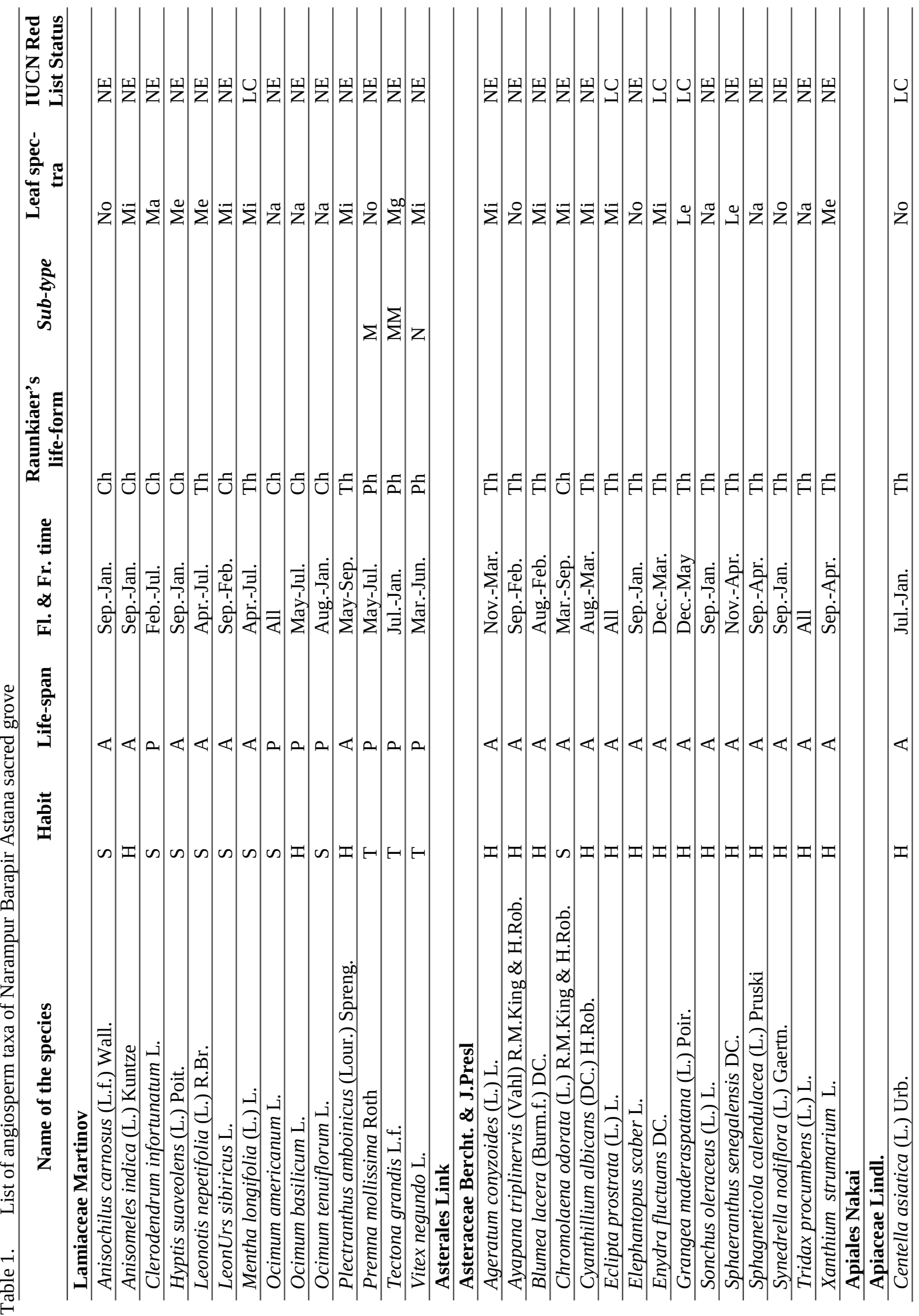

